\title{
Women's Empowerment Model through Development of Households Industry Locally Specific in District of
}

\section{Abang, Karangasem Regency}

\author{
Ni Wayan Sri Astiti ${ }^{1, *}, \quad$ Dwi Putra Darmawan ${ }^{1} \&$ Dewa Gede Raka Sarjana ${ }^{1}$ \\ ${ }^{1}$ Agribusiness Study Program Lecturer, Faculty of Agriculture, Udayana University, \\ Indonesia \\ *Correspondence: Agribusiness Study Program Lecturer, Faculty of Agriculture, Udayana \\ University, Indonesia. E-mail: wayansriastiti@yahoo.co.id
}

Received: October 14, 2017 Accepted: February 8, 2018 Published: May 10, 2018

doi:10.5296/jsr.v9i2.13130 URL: https://doi.org/10.5296/jsr.v9i2.13130

\begin{abstract}
This study aims to identify the profile of households handicraft industries and to propose strengthening women's strategic role models through the development of households industries locally specific. Household industry profiles were analyzed descriptively and The Analytic Network Process (ANP) was selected as women's empowerment priority decision analysis tools and Super Decisions software as supporters.

The results showed that (a) most household's handicraft industries in the District of Abang, Karangasem Regency, Bali Province are classified as business-type starters and undeveloped; (b) rural people assume that women's businesses are conducted merely as a sideline and there has been no attempt to reach a wider market segment; (c) the contribution of women in the household handicraft industry can be summed up very strong, but not as a profitable business for themselves; (d) the results of Analytic Network Process (ANP) showed that the strengthening of the competence of human resources is the best alternative to the empowerment of women by relative priority of $39 \%$.

It is therefore, in applying the strategy of strengthening the competency of human resources, women need to incorporate important strategic orientation and product innovation capabilities in order to expand the business and in turn is able to increase the scale of their business from households scale only becomes SMEs.
\end{abstract}

Keywords: Women's empowerment ANP model, local specific households handicraft industries 


\section{MlMacrothink}

\section{Introduction}

\subsection{Background}

The economics of standards, very little mention of gender and say that the economy consists of the interaction between the company and rational individuals, regardless of gender(genderless). However, while some economists are now starting to consider the role of gender in more detail. Economists of this school of thought that viewpoint 'rational economic man' should not do discrimination and ignoring the role of women. Macroeconomic policy also treats women unfairly. How to measure the existing economy does not take into account the contribution of women. Women perform a variety of households chores, ranging from caring for and provide nutritious food to children and households members are elderly or sick (Darmawan, 2011), cooking, cleaning and so on.

Because women's work is usually not paid as well as in formal economic transactions, it is not counted in national income. Gross Domestic Product is only a partial measure of economic progress because the welfare of mankind depends on many factors, including the position of women in the households. Reduction of total households income, often have a negative impact on women than men because of the great responsibility of women in the households, especially in the case of members of households health and education of children. Moreover, the facts show that the ratios of women's earnings are always under men.

Households economic and role of gender is not a new discourse again today. It must be remembered events monetary crisis that hit the world in 1997/1998 by which time many workers and employees laid off due to economic conditions in the countries in the world many of which reached its nadir. However, at that time Indonesia is not so completely. There is no safety valves, namely the existence of Small and Medium Enterprises (SMEs) become creators of new jobs. In addition, many of them have been instrumental in increasing people's incomes are widely spread, especially in the agricultural sector, especially in rural areas.

\subsection{Objectives}

The objective of this study were (1) identify the typology of household industry in the district of Abang, Karangasem regency, and (2) Creating strategic planning models to increase the role of women through household industry by using Analysis Network Process (ANP).

\section{Methodology}

\subsection{Location and Time of the Research}

The research location in the district of District Abang, Karangasem regency, as the region is still relatively poor in the province of Bali. This region is deemed representative and the potential for the development household industry due to its comparative advantage should not be expressed as poor areas or do not have poor households. Research conducted at the center 
of the craft industry in Karangasem from January to June, 2014.

\subsection{Research Methods}

Critical review on relevant reports published and the results of field observation becomes a reference qualitative descriptive analysis of the domestic industry profile developed in District Abang, Karangasem. Expert meeting was held to choose the elements of the system are believed to be appropriate for the development of the craft industry in rural Karangasem. Respondents were drawn to perform expert meeting were representatives of the Office of UMK, Department of Industry and Trade, chairman of the group, traders, wholesalers / exporters, industry observer's crafts, and academic experts from universities in Bali. Results expert meeting is used as input for the model Analytic Network Process (ANP) (with software Super Decisions as supporters) to manipulate the relationship of dependence and feedback among clusters purpose, aspects, issues and alternative strategies as an integrated solution development handicraft industry in Karangasem.

\section{Results and Discussion}

\subsection{Characteristics of Respondents}

The results showed that the industry is the dominant businesses led by women while in the bamboo business still need a helping hand from the men, especially in the provision of raw materials. Every type of business requires character businessmen. Installation effort of "mute" demanded workers over the age of young women (with an average age of 31.5 years old respondents). Similarly, the coconut shell handicraft business, the average age of respondents was 25.2 years.

Both of these types of businesses require entrepreneurs younger with a sharper eye vision for dealing with the activities of sewing. If the terms of the job, it seems this kind favored by young women as a side job (done when briefly). The amount of family responsibilities (average 4 person / household) shows that the load factor family encourages people to take a second job is. In addition to the requirements of the education level is not high (average of 7.9 years, equivalent to elementary school) who make this industry is the best option for housewives in increasing household income, also sisebabkan can be done while taking care of children at home alone.

\subsection{Households Industry Profile}

Observation and survey results indicate that businesses predominantly women with a lifespan of 12-68 years, and most of the housewives (93\%) and the rest (7\%) active status as a student. The SMEs activities, especially households industry in Abang District is spread into several activities, that is (1) The business activities of convection (sewing and "mute" pairs) with the proportion of $30 \%$ of the total existing businesses; (2) Industrial palm, bamboo woven and cocconut shell craft with the largest number, that is 40\%; (3) Food and beverage home industry, such as meatballs and snacks and "tuak" by 10\%; (4) The business activities of tool-making ceremony "canang sari", "bebanten" and "orti" by 7\%; (5) other industries by 
$13 \%$. When viewed from the contribution to the total household income increase women's participation turned out to be able to contribute as much as $32.82 \%$ as shown in Table 1 .

Table 1. Households Industry Profile Specified According to Industry Group, Households Income, and Households Income Industry

\begin{tabular}{lcccc}
\hline $\begin{array}{c}\text { Households Industry } \\
\text { Group }\end{array}$ & $\begin{array}{c}\text { Business } \\
\text { Actor } \\
\text { (people) }\end{array}$ & $\begin{array}{c}\text { Business } \\
\text { Actor } \\
(\%)\end{array}$ & $\begin{array}{c}\text { Households Incame } \\
\text { (Rp/month) }\end{array}$ & $\begin{array}{c}\text { Industry Incame } \\
\text { (Rp/month) }\end{array}$ \\
\hline Handicraft & 28 & 70 & 1.666 .668 & 526.000 \\
Foods & 4 & 10 & 966.000 & 466.000 \\
Tools ceremony & 3 & 7 & 1.750 .000 & 475.000 \\
Others & 5 & 13 & 1.841 .000 & 575.000 \\
\hline Total & 40 & 100 & 1.555 .917 & 510.666 \\
\hline
\end{tabular}

Although the average income of household industry business person are classified as small (Rp 510,666) compared with total household income is Rp 1,555,917 per month, but it is felt could help alleviate the needs of his family. Low income levels of the craft industry is inseparable from the low distribution of working hours in the field, namely within the range of 2-6 hours and an average of 4.5 hours per day with a frequency of between 15-30 days per month. This happens because most of the industry players still view the work simply as a side job. Awareness of the duties and functions as a housewife becomes a major factor for their families.

The pattern of industrial production activity is based on the local needs with dedication to serve the surrounding residents and communities. In terms of the production activity that depends on the order of business activity only and is done without using the machine. This indicates that this type of industry is indicated as an attempt beginners. Similarly, the results of observation of labor utilization are used, largely using labor in the family (1-2 people) and capitalize not more than Rp 200,000 to Rp 500,000 indicate that the business classified as beginners, except coconut shell craft.

Production activities carried out regularly and do not depend on the existence of the order. This indicates that the profile is classified as a developing business. The wage system is made in a fair and transparent, depending on mutual agreement. The amount of wages that must be received by the employee will depend on the number of units of products and types of products that are biased done at a certain time unit. As though here the craft industry no longer need an office or a particular workplace. Of raw materials and marketing its products, accounted for by the chairman of the group, both in terms of capital as well as the procurement of materials needed. It can be said that the industry as a business venture partnership between the owners of capital (still in a community) with employees as casual workers. In the execution of all parties can coexist in harmony without feeling persecuted each other. Orientation of the broader market has not been a consideration for most 
businesses industry (except coconut shell craft industry), so that the production activity solely because there is an order and certainly not developed.

Things are a little different going on in the business coconut shell craft. Production activities done consistently and not be dependent on the presence or absence of orders from customers. There is no order or continue to run their activity so as to types that can be classified as business began to grow (more advanced). In detail, indicators and categories of household handicraft industry profile is presented in Table 2.

Table 2. Indicators and Category Profile Industry Craft Household in the District of Abang, Karangasem Regency, 2014

\begin{tabular}{|c|c|c|c|}
\hline \multirow[t]{2}{*}{ Indicator } & \multicolumn{3}{|c|}{ Category } \\
\hline & Beginners & Developing & Developed \\
\hline Production activity & Incidental orders & Standing order & fixed production \\
\hline How to sales results & Loose & Wholesale & contract \\
\hline Financial management & Join with the family finances & Sometimes & separate \\
\hline $\begin{array}{l}\text { Working capital (Rp } \\
\text { million) }\end{array}$ & $1-5$ & $5-10$ & $50-200$ \\
\hline Capital resources & Own & Own+ loan & formal credi \\
\hline $\begin{array}{l}\text { Production process } \\
\text { The amount of labor } \\
\text { (people) }\end{array}$ & $\begin{array}{l}\text { Without engine } \\
1-2 \text { of labor outside the family }\end{array}$ & $\begin{array}{l}\text { Semi machines } \\
2-5 \text { family }+ \\
\text { outside }\end{array}$ & $\begin{array}{l}\text { machine } \\
5-10 \text { power } \\
\text { of wages }\end{array}$ \\
\hline Adoption of technology & Nothing & Moderate & high \\
\hline Business ownership & Own & Family business & cooperative \\
\hline Education business people & Low & Moderate & high \\
\hline Criteria Weight & $(1-6)$ & $(7-10)$ & $(11-$ more $)$ \\
\hline
\end{tabular}

\subsubsection{Description of the Craft Industry Ctivities}

These industries utilizing local raw materials, including bamboo craft, craft woven palm, coconut shell waste utilization, and stick palm leaf midrib. Activities such as handicraft production of much-needed local communities in economic activities or religious ritual in Bali. This activity has been used since, based on the order between the local communities and worked as a side job. The type of industry that have these characteristics, covering woven bamboo crafts, woven palm, and crafts "ingka" (the use of a stick, coconut leaf midrib). The type of craft is done independently with their own capital. Found a slightly different character to the coconut shell handicraft industry.

Lately, coconut shell crafts experienced a significant improvement thanks to the guidance and promotion of local trade and industry department. Its products have been spread through out the island. This activity has been carried out since 7 years ago, initiated by the 
government in the form of business groups with 22 people. A form of production, training and coaching is done in groups. In the development, the production activity is no longer carried out in one place.

The existence of the opportunity or the time difference of each member of the group led to an agreement that the product can be done at their homes without working together. Production activities carried out regularly and do not depend on the existence of the order. This indicates that the profile is classified as a developing business.

\subsubsection{Description of the Convection Services Activities}

The industrial activity was originally initiated by the government and conducted in groups on 2013.Awalnya, businesses who are interested to be developed and trained a total of 20 people, each 10 tailors and 10 mounting mute, currently active now only 15 people. This industry is tailoring service provision and installation of accessories mute. Informed that this work as a sideline and the production based on orders only, and may be done simultaneously as a housewife and does not need a lot of capital, so that it can be regarded as an independent activity of each offender. Production activities will not be fixed, based on the order, and carried out by businesses in their homes with their own capital. However, the marketing of products is done by building networks of information between actors through the head of the group or access information from members of the own group.

\subsubsection{Food Production Industry Activity}

Other industries, such as the production of snacks, cooking oil (coconut oil), making meatballs, an effort that is entirely done independently, both in terms of capital, enterprise management, finance and others. Production activities carried out based on orders that are incidental. This activity is growing and evolving long ago, the only use of labor in the family, as well as its nature as a side job or just spare time only.

\subsection{Analytic Network Process (ANP)}

Planning strategies to empower women through households industries is using the Analytic Network Process (ANP). ANP allows for dependencies and feedback, both within and between clusters. ANP is composed of two parts, namely (a) the hierarchy / network control and subcriteria that control dependencies in the system under study; (b) the effect of inter-element networks and clusters (Saaty, 2003). Figure 1 shows the general framework of the model of ANP for the households industries. This network has four clusters, namely: purpose, aspect, problem and strategy. Cluster "aspect" has two elements, the cluster "problem" has five elements, and cluster "strategy" has five elements ( Astiti, at.all, 2014).

From the results of the expert meeting that has been done, the problems faced by the households industries can be classified into internal and external aspects. Internal problems faced by the households industries are building and machinery investment is limited, weak competence of human resources, and weak marketing function. External problems faced by the households industries are the entrepreneurial spirit of the community is weak and subordination of women. There are five alternative of the strategy for developing the strategic 
role of women through locally specific households industry, namely: partnerships synergy, strengthening of the human resource competencies, institutional strengthening, strengthening of marketing functions, and stimulus for the application of machine technology and equipment. Data were obtained by questionnaires by experts using paired comparison then processed using the Super Decision software to obtain the synthesis of priorities (Table 3) (Astiti, at.all, 2014).

Based on data from Table 3, it appears that the main aspects to consider in looking for an alternative development strategy home industry are the internal aspect with the average weight of 0.64. From the internal aspect, the main issues considered most important is competence of human resources weak with the average weight of 0.30 , while the most external problems received attention is the weak social entrepreneurial spirit with the average weight of 0.26 .

Alternative strategies are formulated for the households industries are five, namely synergy of partnerships, strengthening the competence of human resources, institutional strengthening, strengthening the marketing function, and technology applications stimulus of machinery and equipment. The strategy is a top priority in developing the home industry in rural areas is strengthening the competence of human resources with a weight of 0.39 (the best alternative to the relative priority of $39 \%$ ).

Table 3. Priority Synthesis of Households Industrial Development Using ANP

\begin{tabular}{lc}
\hline & Priority \\
\hline Aspect & 0.56 \\
\hline Internal & 0.44 \\
External & \\
Problem & 0.30 \\
Weak of competence of human resources & 0.12 \\
Building and machinery investment is limited & 0.26 \\
The entrepreneurial spirit of the community is weak & 0.13 \\
Weak of marketing function & 0.19 \\
\hline Subordination of women & 0.11 \\
\hline Strategy & 0.39 \\
\hline Partnerships synergy & 0.15 \\
Strengthening of the human resource competencies & 0.15 \\
Institutional strengthening & 0.20 \\
Strengthening of marketing functions & \\
Stimulus for the application of machine technology and equipment & \\
\hline
\end{tabular}

In applying the strategy of stengthering the competency human resources, there are two approaches that can be done, namely the strengthening of the marketing function that human resources is able to build a brand image of the product on the market as well as innovation 


\section{Macrothink}

and learning so that their products have a competitive advantage (Porter, 1980; Porter, 1985; Barney, 1991; The British Council, 2010; grawe et al., 2009). Study of SMEs creative business showed a close relationship between strategic orientation, innovation capability and firm performance (Kandampully, 2002; Keskin, 2006; Rahab and Sudjono, 2011; Kumar et al., 2012; Manurung and Barlian, 2012).

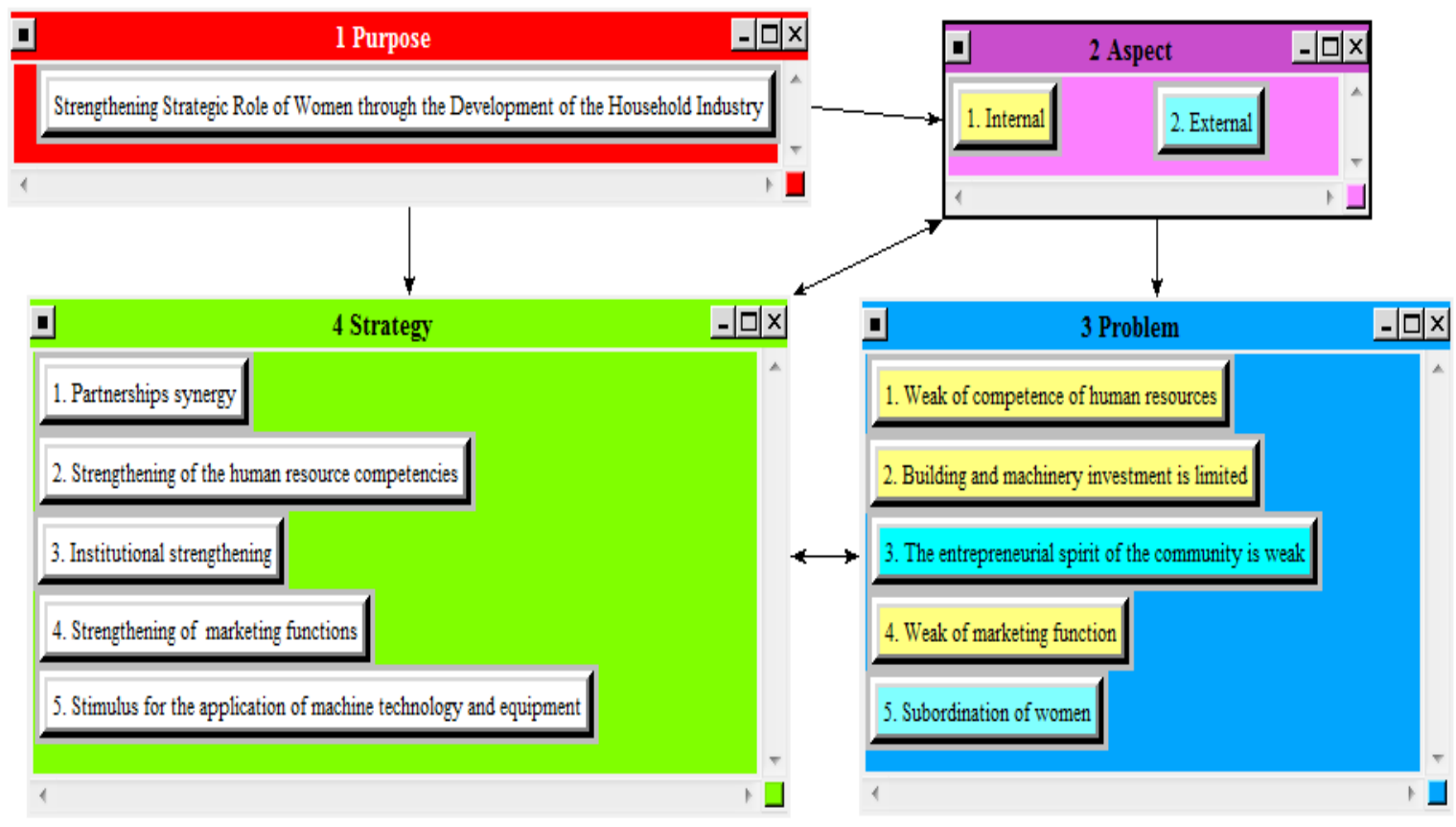

Figure 1. Model of Women's Empowerment Through Househol's Craft Industry Development Rural Area (Astiti, at all. 2014)

In an effort to foster competence of human resources, women can incorporate important strategic orientation and ability to craft innovative products that benefit home industry forward. Marketing functions that still need to be strengthened is the design and development of products, the smooth distribution of products, standardization and grading of products, packaging, labeling and branding, marketing information (for example, through the website, including the introduction of online transactions), and resistance to business risk (risk-taking). Although coconut shell craft industry has had a strong product position and clear market segments, strengthening internal business should continue to be made. Business expansion outside the territorial Karangasem by establishing strategic partnerships need to be planned carefully.

\section{Conclusion and Managerial Implications}

\subsection{Conclusion}

Exposure based on the analysis above, the conclusions of this research are as follows. 


\section{$\Lambda$ Macrothink}

1. Most household's handicraft industries in the District of Abang, Karangasem Regency, Bali Province are classified as business-type starters and undeveloped;

2. Rural people assume that women's businesses are conducted merely as a sideline and there has been no attempt to reach a wider market segment;

3. The contribution of women in the household handicraft industry can be summed up very strong, but not as a profitable business for themselves;

\subsection{Managerial Implications}

1. In applying the strategy of strengthening the competency of human resources, women need to incorporate important strategic orientation and product innovation capabilities in order to expand

the business and in turn is able to increase the scale of their business from households scale only becomes SMEs.

2. Strengthening the marketing function for women who are involved in this households industry

needs to be done in order to awaken the brand image of the households products industry both in the local market and in turn are able to expand outside the province of Bali.

3. Given the typical households industrial clusters based on local resources and innovation capabilities of rural women is an important factor in the development of creative small and medium enterprises, government (cq. Empowering Ministry of Women and Child Protection, the Ministry of SMEs and Cooperatives, Ministry of Trade, and the Ministry of Tourism and Creative Economy) and the local government of Bali, is expected to encourage the expansion and growth of the craft industry in line with the road map for development of Indonesia's Creative Economy in 2025.

\section{Acknowledgements}

We would like to grateful to The Director General of Higher Education, The Ministry of Education and Culture of Indonesia for their support and provision of grant funding for this research.

\section{References}

Astiti, Sri, Darmawan DP., \& Sarjana, raka. (2014). Strenghening Women<s Strategig Role Through Localy Specific Houshole Industry in Bali, Indonesia. IISTE, 4(26).

Barney, J. (1991). Firm resources and sustained competitive advantage. Journal of Management, 17(1), 99-120. https://doi.org/10.1177/014920639101700108

British Council. (2010). Mapping the Creative Industries: A Toolkit. London: The British 
Council.

Darmawan, D.P. (2014). Strategi pembangunan ketahanan pangan dan daya tahan ekonomi masyarakat miskin di perdesaan Bali. Makalah dipresentasi kanpada Seminar "StrategiImplementasi Program Bali MandaraJilid II: HarapandanKendala di Era Otonomi Daerah", diselenggarakan atas kerjasama Universitas Udayana dan Pemprov Bali, di GedungWiswasaba, Kantor Gubernur Bali, Denpasar, 25 September 2014.

Global Business Guide Indonesia. (2012). Indonesia Creative Industries. Retrieved on November 9, 2013 from Official Website of GBG Indonesia http://www.gbgindonesia.com/en/services/article/2011/indonesia_s_creative_industries.p hp.

Grawe, S.J., Chen, H., \& Daughtery, P.J. (2009). The relationship between strategic orientation, service innovation, and performance. International Journal of Physical $\begin{array}{lll}\text { Distribution \& Logistics } \quad \text { Management, } & 39(4), & 282-300 .\end{array}$ https://doi.org/10.1108/09600030910962249

Kandampully, J. (2002). Innovation as the core competency of a service organisation: The Role of Technology, Knowledge, and Networks. European Journal of Innovation Management, 5(1), 18-26. https://doi.org/10.1108/14601060210415144

Keskin, H. (2006). Market orientation, learning orientation, and innovation capabilities in SMEs. European Journal of Innovation Management, 9(4), 396-417. https://doi.org/10.1108/14601060610707849

Kumar, K., Boesso, G., Favotto, F., \& Menini, A. (2012). Strategic orientation, innovation patterns and performances of SMEs and large companies. Journal of Small Business and Enterprise Development, $\quad 19(1), \quad 132-145$. https://doi.org/10.1108/14626001211196442

Manurung, E.M., \& Barlian, I. (2012). From small to significant: Innovation process in small-medium creative businesses. International Journal of Innovation, Management and Technology, 3(6), 788-792.

Porter, M.E. (1985). Competitive Advantage. New York, NY: The Free Press.

Rahab, Sulistyandari \& Sudjono. (2011). The development of innovation capability of small medium enterprises through knowledge sharing process: An Empirical Study of Indonesian Creative Industry. International Journal of Business and Social Science, 2(21), 112-123.

Saaty, R.W. (2003). Decision Making in Complex Environments. The Analytic Hierarchy Process (AHP) for Decision Making and The Analytic Network Process (ANP) for Decision Making with Dependence and Feedback. Pittsburgh: The Creative Decisions Foundation.

Susrusa, IK.B., Antara, M., \& Sri Astiti, N.W. (2009). Monitopringdan evaluasi program pengembangan kecamatan dalam mengentaskankemiskinan di Provinsi Bali. Denpasar: 
Fakultas Pertanian.

Universitas Udayana, LaporanPenelitianHibahPenelitianStrategisNasionalTahun 2009. Darmawan, D.P. 2011. Ketahanan Pangan Rumahtangga dalam Konteks Pertanian Berkelanjutan. Denpasar: Udayana University Press.

World Bank. (1994). Indonesia: Sustaining Development, Washington DC.

\section{Copyright Disclaimer}

Copyright for this article is retained by the author(s), with first publication rights granted to the journal.

This is an open-access article distributed under the terms and conditions of the Creative Commons Attribution license (http://creativecommons.org/licenses/by/3.0/). 